\title{
The differences in metabolic responses between dietary orotate and adenine in lipid profiles of serum and liver tissues
}

\author{
Yohanes Buang ${ }^{1,2}$ \\ ${ }^{1}$ Department of Chemistry, Faculty of Science and Engineering, Nusa Cendana University, Jln. Adisucipto Penfui-Kupang, Indonesia \\ ${ }^{2}$ Laboratory of Applied Biochemistry, Department of Applied Biological Science, Saga University, Saga Shi, Honjo Machi-1, \\ Saga, Japan
}

\begin{abstract}
Abstrak
Tujuan: Menyelidiki perbedaan respons metabolik terhadap asupan diet mengandung orotat dan diet mengandung adenin pada profil lipid dalam serum dan jaringan hati.

Metode: Tikus-tikus percobaan diberi diet yang mengandung orotat 1.0\% (kelompok orotat) dan adenin 0.25\% (kelompok adenin) atau diet yang tak disuplementasi (kelompok kontrol) selama 10 hari. Kadar lipid dalam serum diukur menggunakan enzyme assay kits. Lipid jaringan hati diekstraksi dan konsentrasinya ditentukan.

Hasil: Kadar serum lipid kelompok adenin cendrung meningkat, sebaliknya kelompok orotat cendrung menurun dibandingkan dengan kelompok kontrol. Kadar serum trigliserida (mg/dL) pada kelompok kontrol, orotat, dan adenin

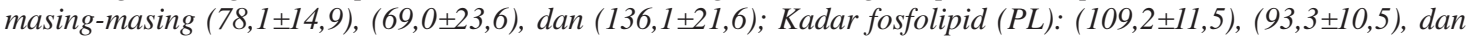

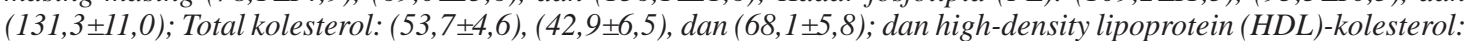
$(35,4 \pm 2,7),(33,0 \pm 3,0)$, dan $(44,7 \pm 2,7)$. Kandungan TG hati pada kelompok orotat meningkat tajam mendekati 10-kali lipat dibandingkan dengan kelompok kontrol $(P<0,05)$, sebaliknya kandungan TG kedua kelompok lainnya hampir sama. Kandungan lipid jaringan hati (mg/g jaringan) pada ketiga kelompok dimaksud masing-masing untuk TG adalah: (11,4 $\pm 1,3),(123,5 \pm 15,2)$, dan $(11,9 \pm 1,2)$; $P L:(27,1 \pm 0,8),(25,4 \pm 1,3)$, dan $(30,7 \pm 0,6)$; dan total kolesterol: $(2,73 \pm 0,09),(2,34 \pm 0,12)$, dan $(2,91 \pm 0,08)$. Kandungan $P L$ dan kolesterol hati pada kelompok adenin masing-masing meningkat sebesar 21\% dan 25\% dibandingkan dengan kelompok orotat, tetapi kandungan kedua jenis lipid tersebut pada kelompok terakhir ini menurun masing-masing sebesar 7\% dan 15\% dibandingkan dengan kelompok kontrol.
\end{abstract}

Kesimpulan: Dietary adenin menginduksi sekresi lipid ke dalam aliran darah dan transport balik kolesterol menuju sel-sel hati. Sebaliknya dietary orotat cendrung mempertahankan lipid-lipid yang telah disintesis di sel-sel hati, terutama TG, dan mengurangi sekresi. (Med J Indones 2010; 19:217-22)

\begin{abstract}
Aim: Objectives To evalate the differences in metabolic responses between dietary orotic acid and adenine in lipid profiles of serum and liver tissues.

Methods: Rats were paired-fed $1.0 \%$ orotic acid (orotic acid group) and $0.25 \%$ adenine (adenine group) diets or a non-supplemented diet (control group) for 10 days. Serum lipid concentrations were measured using enzyme assay kits. Lipids of liver tissues were extracted and the lipid contents were determined.

Results: Serum lipid concentrations (in $\mathrm{mg} / \mathrm{dL}$ ) of adenine group tended to increase whereas those levels decreased in orotic acid group compared to control group. The serum triglyceride (TG) concentrations of control, orotic acid, and adenine groups were (78.1 \pm 14.9$),(69.0 \pm 23.6)$, and (136.1 \pm 21.6$)$; phospholipids (PL): (109.2 \pm 11.5$),(93.3 \pm 10.5)$, and (131.3 \pm 11.0$)$; total cholesterol: (53.7 \pm 4.6$),(42.9 \pm 6.5)$, and (68.1 \pm 5.8$)$; and high-density lipoprotein (HDL)-cholesterol: (35.4 \pm 2.7$),(33.0 \pm 3.0)$, and (44.7 \pm 2.7$)$, respectively. Furthermore, liver TG content of orotic acid group markedly increased. The increase was approximately by 10 -fold in comparison to other groups $(\mathrm{P}<0.05)$. The lipid contents of liver tissues (in $\mathrm{mg} / \mathrm{g}$ tissue) in ordinarily of those three groups for TG were (11.4 \pm 1.3$),(123.5 \pm 15.2)$, and (11.9 \pm 1.2$)$; PL: (27.1 \pm 0.8$),(25.4 \pm 1.3)$, and (30.7 \pm 0.6$)$; and the total cholesterol: $(2.73 \pm 0.09),(2.34 \pm 0.12)$, and (2.91 \pm 0.08$)$, respectively. The liver PL and cholesterol content of adenine group increased by $21 \%$ and $25 \%$ than that of orotic acid group, but both lipid levels of the latter group increased by $7 \%$ and $15 \%$, respectively, than that of the control group.
\end{abstract}

Conclusion: Dietary adenine enhances the serum TG, PL, cholesterol, and HDL-cholesterol and the liver PL and cholesterol but without alters the liver TG levels. Dietary orotic acid, however, attenuates these serum lipid levels but retains those lipids synthesized in liver cells, mainly TG. (Med J Indones 2010; 19:217-22)

Key words: Adenine, liver lipids, lipogenesis, orotic acid, serum lipids 
Orotate (orotic acid) is a parent compound of pyrimidine base. It is reported that orotic acid is a minor dietary constituent, ${ }^{1}$ and therefore, it had been known as vitamin B-13 until it was realized that it could be synthesized by humans. ${ }^{2}$ The richest dietary sources are cow's milk and other dairy products ${ }^{3}$, as well as root vegetables such as carrots and beets. ${ }^{1}$ Currently, orotic acid is known as an intermediate metabolism of pyrimidine nucleotides. The orotic acid involved in the body's cells, therefore, is provided from the diets and the de novo biosynthesis.

The nucleotides containing purine base include the adenine. Adenine and its derivatives play a variety of roles in biochemistry including an integral part of the structure of many coenzymes such as nicotinamide adenine dinucleotide-reduced forms (NADH) and flavine adenine dinucleotide $\left(\mathrm{FADH}_{2}\right)$, and nicotinamide adenine dinucleotide phosphate (NADPH). The NADH and $\mathrm{FADH}_{2}$ molecules play major roles in cellular respiration to generate adenosine triphosphate (ATP), a high energy-containing molecule. ${ }^{4-6}$ The pathogeneses of the lipid metabolism disorders are mostly contributed by the low level of ATP production generated by the aerobic mechanisms.

Both orotic acid and adenine compounds are the base components of the nucleotides; in which they are the functional units of the nucleic acids and essential compounds in protein biosynthesis, ${ }^{4,7}$ such as biosynthesis protein components of the very-low density lipoprotein (VLDL). VLDL is a lipoprotein handling the lipid transportation from the synthesized lipid in the liver into extra hepatic tissues. The reduction of mature VLDL level, therefore, can induce the differentiation in serum lipid profiles. Hence, a serum lipid profile generally indicates how lipid metabolism occurred in the liver. Pottenger et al $^{8}{ }^{8}$ reported that dietary orotic acid attenuated the VLDL secretion but did not interfere with the protein biosynthesis. This report is consistent with our previous study and the others that serum lipids level was decreased in orotic acid-treated rats $^{9-12}$ but there was accompanied with an excessive accumulation of fats in liver. It is known that orotic acid is the oxidator agent and reduced in metabolic reactions but adenine derivative such as NADH and NADPH is the reductor and oxidized in the metabolic reactions. ${ }^{4}$ The structures of these compounds and their redox reactions in metabolisms are depicted in Fig.1 $(a, b)$. Both these molecules therefore were assumed to play an important role in differentiation of lipid metabolisms. ${ }^{4}$ The adenine intake, therefore, might reverse the trend of serum and liver lipids. However, there were no data that has been tested this hypothesis. Thus, it is of interested to elucidate the differences in the metabolic responses between dietary orotic acid and adenine in lipid profiles of serum and liver tissues.

\section{METHODS}

\section{Animals and experimental design}

All aspects of the experiment were conducted according to guidelines provided by the ethical committee of experimental animal care at Saga University (Saga, Japan). Male Sprague-Dawley rats aged 5 weeks were housed individually in an air-conditional room $\left(24^{\circ} \mathrm{C}\right)$ with a 12-h light/dark cycle. After a 1-wk adaptation period, rats were assigned to three groups (five rats each). Control diet (as control group) was prepared according to recommendations of the American Institute of Nutrition (AIN) and contained (in weight \%) 20 of casein, 10 of safflower oil, 1 of vitamin mixture (AIN93), 3.5 of mineral mixture (AIN-93), 0.20 of choline bitartrate, 0.3 of DL-Methionine, 5 of cellulose, 15 of $\alpha$-cornstarch, and sucrose to make 100 . The orotic acid (as orotic acid group) and adenine (as adenine group) diets were prepared by replacement of $1.0 \%$ sucrose with orotic acid and $0.25 \%$ with adenine, respectively, to the control diet. The animals received the diets for 10 days. At the end of the feeding period, rats were killed by decapitation after a 9-h starvation. Livers were excised immediately, and serum was separated from blood.

\section{Analyses of serum and liver lipids}

Liver lipids were extracted according to the method of Folch et al. ${ }^{13}$ and concentrations of triglyceride (TG) and phospholipids (PL) were measured by the methods of Fletcher ${ }^{14}$ and Bartlett, ${ }^{15}$ respectively. The total cholesterol (Liver Chol) content was measured by the methods of Sperry and Webb ${ }^{16}$ with a minor adaptation. Serum TG, PL, and cholesterol were measured using enzyme assay kits from Wako Pure Chemicals according to the manufacture's instructions.

\section{Preparation of liver sub cellular fractions}

The mitochondrial and cytosol of liver sub cellular fractions were prepared as previously reported by Nagao et al. ${ }^{17}$ Protein concentration was determined by the method of Lowry et al. ${ }^{18}$ 


\section{Assays of hepatic enzyme activity}

The lipogenic enzyme determined was fatty acid synthase (FAS; EC2.3.1.85). The activities of FAS enzyme were determined as previously described by Nagao et al. ${ }^{17}$. The lipolytic enzyme determined was carnitine palmitoyl transferase-1 (CPT; EC2.3.1.23), a rate-limiting enzyme of fatty acid $\beta$-oxidation. The activities of CPT enzyme were also measured as previously reported by Nagao et al. ${ }^{17}$

\section{Statistical analyses}

All values are expressed as mean \pm standard error of the mean (SEM). Data were analyzed by one-way analysis of variance, and all differences were inspected by Duncan's new multiple-range test using SSPS statistical software (SSPS inc., Chicago, IL, USA) ${ }^{19} \mathrm{P}<0.05$ was considered statistically significant.

\section{RESULTS}

\section{Dietary orotic acid promoted liver weight}

The daily adjusted food intake is shown in Table 1.Although food intakes were nearly similar among the groups, the final body weights were slightly decreased by those drugs.
Interestingly, the weights of liver were significantly higher in orotic acid group and slightly decrease in adenine group than that of the control group $(\mathrm{P}<0.05)$.

Table 1. The differences in metabolic responses on growth parameters

\begin{tabular}{llll}
\hline Group & Control & Orotic acid & Adenine \\
\hline Initial body weight $(\mathrm{g})$ & $166 \pm 4$ & $167 \pm 4$ & $165 \pm 5$ \\
Final body weight $(\mathrm{g})$ & $210 \pm 3$ & $208 \pm 6$ & $204 \pm 4$ \\
Food intake (total, in gram) & $154 \pm 0$ & $154 \pm 2$ & $153 \pm 2$ \\
Liver weight (g/100 g body weight) & $4.4 \pm 0.2^{\mathrm{a}}$ & $5.8 \pm 0.3^{\mathrm{b}}$ & $4.1 \pm 0.1^{\mathrm{a}}$ \\
\hline
\end{tabular}

Values are expressed as mean \pm SEM of five rats. ${ }^{\text {ab }}$ Different letters indicate significant differences at $\mathrm{P}<0.05$.

\section{Dietary orotic acid induced liver triglyceride level markedly}

Fig. 2 shows the differences in liver lipid contents. Dietary orotic acid increased markedly the liver TG content than that of the other groups $(\mathrm{P}<0.05)$. The increase reached 10-fold in comparison to control group. Both liver PL and liver Chol contents, however, decreased slightly in the group. Interestingly, the liver TG content of adenine group was unchanged in comparison to control group. The liver PL and liver Chol contents however were higher than that of the other groups (Fig. 2) $(\mathrm{P}<0.05)$.

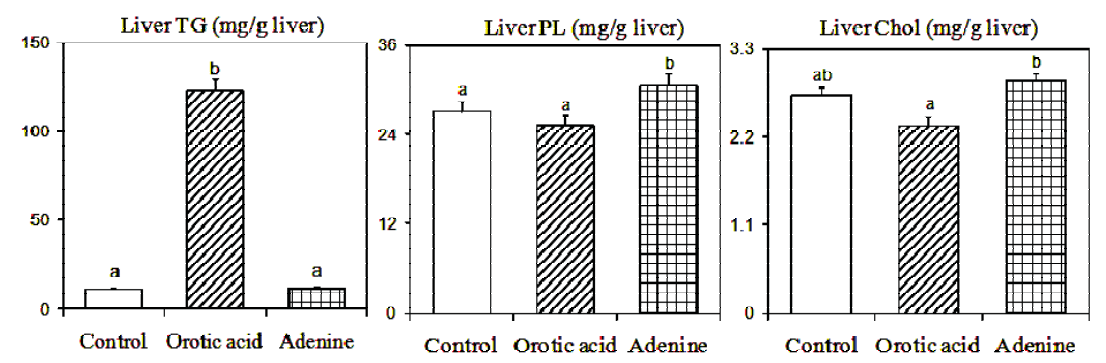

Figure 2. The liver lipids content in control group and in rats fed with orotic acid or adenine. Values are expressed as mean \pm SEM of five rats. abDifferent letters indicate significant differences at $\mathrm{P}<0.05$.

\section{Dietary adenine enhanced serum lipids level}

As shown in Fig. 3, the lipid levels of adenine group increased in serum concentration, in which serum TG, PL, and total cholesterol level increased approximately by $74 \%, 20 \%$, and $27 \%$, respectively, than that of the control group. The high-density lipoprotein (HDL)-cholesterol also significantly increased. Dietary orotic acid however decreased slightly the serum TG, PL, total cholesterol, and HDL-cholesterol level than that of the control group.

\section{Dietary orotic acid stimulated activities of lipogenic but attenuated lipolytic enzymes}

The lipogenic and lipolytic enzymes determined in present study were FAS and CPT-1. As shown in Fig. 4 , dietary orotic acid and that of adenine promoted FAS activity by $32 \%$ and $46 \%$, respectively. The CPT- 1 activity however decreased either in orotic acid or adenine group approximately by $28 \%(\mathrm{P}<0.05)$. 
Serum TG $(\mathrm{mg} / \mathrm{dL})$

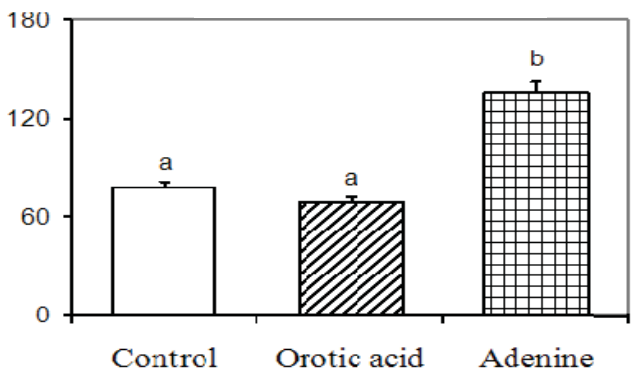

Serum TG $(\mathrm{mg} / \mathrm{dL})$

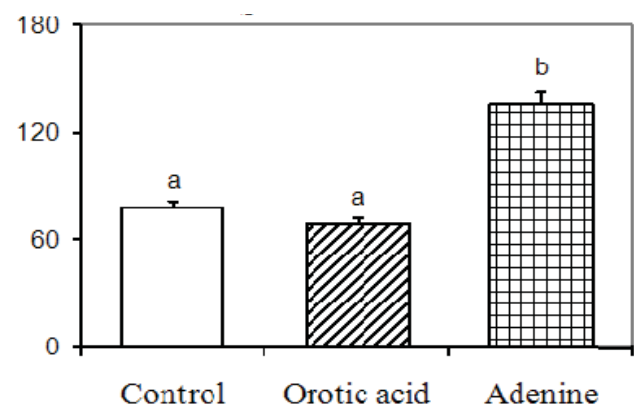

Serum TG $(\mathrm{mg} / \mathrm{dL})$

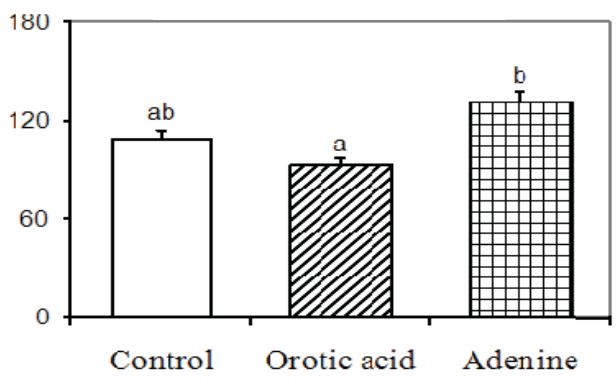

Serum TG $(\mathrm{mg} / \mathrm{dL})$

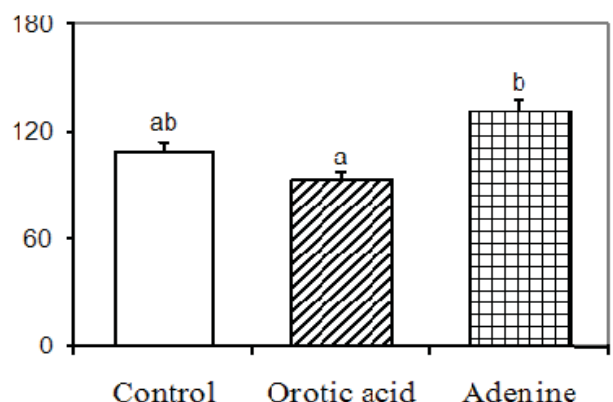

Figure 3. Serum lipids level in control group and in rats fed with orotic acid or adenine

Values are expressed as mean \pm SEM of five rats.abDifferent letters indicate significant differences at $\mathrm{P}<0.05$.
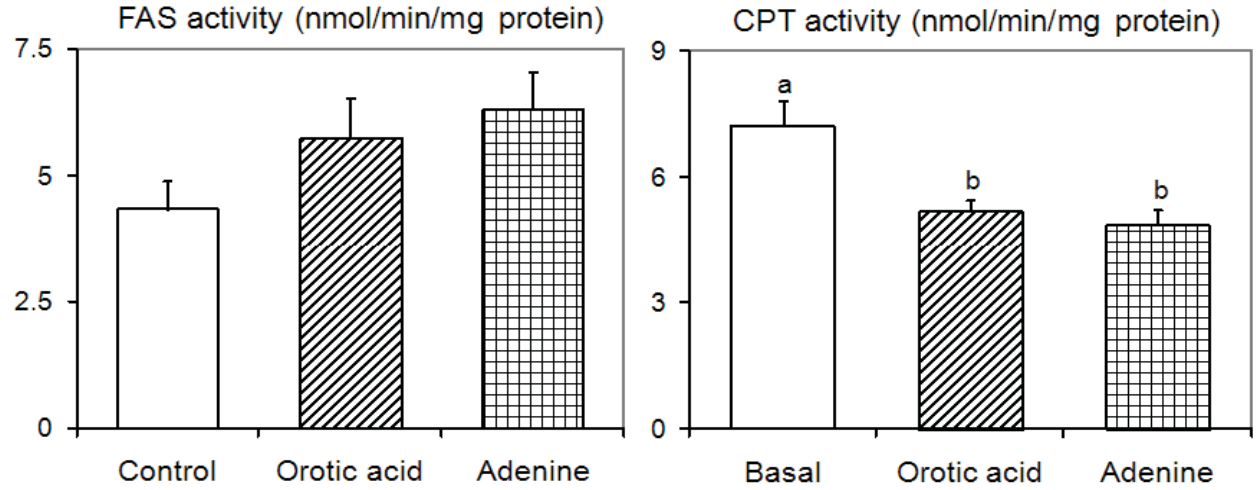

Figure 4. The activities of lipogenic and lipolytic enzymes

Values are expressed as mean $\pm \mathrm{SEM}$ of five rats. abDifferent letters indicate significant differences at $\mathrm{P}<0.05$.

\section{DISCUSION}

It is well known that liver is a main organ of lipid metabolism ${ }^{20}$ and the serum lipid profiles indicate how lipid metabolism occurred in liver cells. The drugs such as orotic acid and adenine derivatives in certain doses induce differentiation in lipid metabolism. The dose of orotic acid $1.0 \%$ is usually used to interpret the metabolic responses in various purposes such as liver function and fatty liver ${ }^{8-11}$ and the $0.25 \%$ dose of adenine is generally used. Either orotic acid or adenine is a minor component found in daily human food. Both compounds therefore include the integral component of the human body. However, there were no studies to establish the differences in metabolic responses between dietary orotic acid and adenine. The present study was conducted to elucidate the differences in the metabolic responses between dietary orotic acid and adenine in lipid profiles of serum and liver tissue, the indicators of the morbidity related to the lipid metabolism disorders. 
As shown in Table 1, the addition of $0.25 \%$ adenine moderately reduced body weight in animals treated after 10 days of time course, although there were similar in the amount of food intake. Those body weight decreases were slightly lower than that of the orotic acid group $(\mathrm{P}<0.05)$. Interestingly, the liver sizes of the control and adenine groups were comparable. However, dietary food fortified with orotic acid induced liver weight significantly than that of the other groups $(\mathrm{P}<0.05)$. Those results indicated that growth parameters were nearly similar among the groups, except the liver weight.

The alteration of liver weight might indicate the differentiation in liver lipid content. As shown in Fig. 2 , the liver TG content of orotic acid group increased markedly than that of the other groups $(\mathrm{P}<0.05)$, whereas both liver PL and cholesterol slightly decreased. The liver TG content of adenine group however was similar level with the control group. The liver PL and cholesterol contents of the adenine group were higher than that of the control group $(\mathrm{P}<0.05)$. It is well accepted that the alteration of lipid content in the liver can result from two mechanisms: 1) impairment of secretion of VLDL from the liver, or 2) the increased expression of lipogenic enzymes and genes combined with the impaired entry of fatty acids into the mitochondrial $\beta$-oxidation pathway. ${ }^{8}$ Hence, VLDL particle handles the transportation of lipid compounds from the liver into extra-hepatic tissues. Lehninger et al. ${ }^{4}$ reported that the increasing lipid packed into the VLDL particle releases high lipid concentration in serum.

To investigate the underlying mechanism by which dietary orotic acid and adenine changed the lipid content in the liver; the serum lipids level and hepatic enzyme activities involved in fatty acid synthesis and degradation were determined. Fig. 3 shows serum TG, PL, total cholesterol, and HDL-cholesterol levels of adenine group in starvation rats were higher than that of the other groups $(\mathrm{P}<0.05)$. Dietary orotic acid however reduced their level in comparison to the control group. The amelioration of serum lipid level by the orotic acid drug intake indicated that VLDL formation decreased in liver tissue. This result is consistent with the reports of Pottenger et al. ${ }^{8}$ that orotic acid treatment interferes the secretion of VLDLs rather than with the synthesis of their protein. Furthermore, the HDL-cholesterol is function to reverse the transportation of cholesterol compound from extra-hepatic into the liver tissue. ${ }^{4}$ It was therefore the high level of HDL-cholesterol (adenine group) in blood indicated a good response of the liver cells related to the treatment. As shown in Fig. 3, the high level of serum total cholesterol was accompanied with an enhancement of HDL-cholesterol level. The alteration of those serum lipids content in starvation rats indicated the differences in lipid secretion from the liver tissue. Overall, these profiles of serum lipids indicated that lipids secretion from the liver was promoted by the adenine but attenuated by orotic acid treatments. The promotion of liver PL and cholesterol contents of adenine group accompanied with an elevation of serum PL and cholesterol level therefore might indicate that biosynthesis rates of these PL and cholesterol levels increased but degradation decreased.

To clarify further whether differentiation in lipid profiles of serum and liver tissues is associated with the differentiation of the lipolytic and lipogenesis by those treatments, the activities of lipogenic and lipolytic enzymes were determined. Fig. 4 shows that FAS activity of orotic acid and adenine group was higher than that of the control group $(\mathrm{P}<0.05)$, in which the increase in adenine group was higher, although it was failed to reach significant level. This data suggested that both treatments induced fatty acids biosynthesis. The lowered CPT-1 activity in these treatments indicated the degradation of fatty acids decreased (Fig. 4). Overall, dietary orotic acid and adenine in separated treatments generated similar effects on lipogenesis and lipolytic, in which both substances promoted fatty acid biosynthesis but attenuated the degradation. Both treatments might induce FAS gene transcription but not mitochondrial $\beta$-oxidation.

In conclusion, dietary adenine induces lipid secretion from the hepatic tissues into the blood stream and reverse transportation of cholesterol from extra hepatic tissues into the liver. Contrarily, the dietary orotic acid tends to retain those lipids synthesized in liver cells, mainly TG, and attenuates their secretions.

\section{Acknowledgments}

The author would like to express high appreciation for the suggestions and the continued encouragement from Dr. Yanagita, the Professor of Saga University, and excellent assistance of Dr. Koji Nagao in enzymatic determinations and the useful assistance from Dr. Yu-Ming Wang in handling instruments and animals. The author also would like to give thanks to the Japanese Monbukagakusho for providing the fund of the research. 


\section{REFERENCES}

1. Salerno C, Crifo C. Diagnostic value of urinary orotic acid levels: applicable separation methods. J Chrom. B Analyt Technol Biomed Life Sci. 2002; 781:57-71.

2. Vandamme EJ. Production of vitamins, coenzymes and related biochemicals by biotechnological processes. J Chem Technol Biotechnol. 1992; 53:313-27.

3. Motyl T, Krzeminski J, Podgurniak M, Witeszczak C, Zochowski P. Variability of orotic acid concentration in cow's milk. Endocr Regul. 1991; 25:79-82.

4. Lehninger, Nelson, Cox. 1993, Principles of Biochemistry $2^{\text {nd }}$ ed. Worth Publishers, Inc. USA.

5. Stipanuk MH. Biochemical, Physiological, and Molecular Aspects of Human Nutrition. $2^{\text {nd }}$ Ed., 2006. Published by Saunders-Elsevier, New York: page 666-72.

6. Allen L, deBenoist B, Dary O. Guidelines on food fortification with micronutrients. WHO Library Cataloguing-in-Publication Data. 2006; 73-80.

7. Websitehttp://ghr.nlm.nih.gov/ghr/glossary/adenine.Accessed July 10, 2009.

8. Pottenger LA, Gets GS. Serum lipoprotein accumulation in the livers orotic acid-fed rats. J lipid Res. 1971;12: 450-9.

9. Buang Y, Wang YM, Cha JY, Nagao K, Yanagita T. Dietary phosphatidylcholine alleviates fatty liver induced by orotic acid. Nutrition. 2005; 21: 867-73.

10. Buang Y, Cha JY, Nagao K, Wang YM, Inoue N, Yanagita T. Alleviation of fatty liver by $\alpha$-linolenic acid. J Nutr Sci Vitaminol. 2004; 50: 272-6.
11. Miyazawa S, Furuta S, Hashimoto T. Reduction of $\beta$-oxidation capacity of rat liver mitochondria by feeding orotic acid. Biochim. Biophys. Acta. 1982; 711: 494-502.

12. Cha JY, Cho YS, Kim I, Anno T, Rahman SM, Yanagita T. Effect of hesperetin, a citrus flavonoid, on the liver triacylglycerol content and phosphatidate phosphohydrolase activity in orotic acid-fed rats. J Plant Foods Human Nutr. 2001;17:1-10.

13. Folch J, Lees M, Sloane-Starley GH. A simple method for the isolation and purification of total lipids from animal tissues. J. Biol. Chem.1957; 226:497-509.

14. Fletcher MM. A colorimetric method for estimating serum triglycerides. Clin. Chim. Acta. 1968; 22:393-7.

15. Barlett GR. Phosphorous assay in column chromatography. J. Biol. Chem.1959; 234: 466-8.

16. Sperry WM, Webb M. A revision of the schoenheimersperry method for cholesterol determination. J. Biol. Chem. 1950;187: 97-106.

17. Nagao K, Wang YM, Inoue N, Han SY, Buang Y, Noda T, et al. The 10trans, 12cis Isomer of Cunjugated Linoleic Acid Promotes Energy Metabolism in OLETF Rats. Nutrition. 2003; 19, 7-8: 652-6.

18. Lowry OH, Rosebrough NJ. Farr AL. Randal RJ. Protein measurement with the Folin phenol reagent. J Biol Chem. 1951;193: 265-75.

19. Duncan DB. Multiple range and multiple F Test. Biometric. 1955;11: 1-42.

20. Li Z, Clark J, Diehl AM. The liver in obesity and type 2 diabetes mellitus. Clin Liver Dis. 2002; 6: 867-77. 